\title{
Mainstreaming Disaster Risk Reduction into Housing Development in Keko Machungwa
}

\author{
Tumpale Sakijege \\ Department of Urban and Regional Planning, Ardhi University, Dar es Salaam, Tanzania \\ Email: tumpaleg@yahoo.com, tumpaleg@gmail.com
}

How to cite this paper: Sakijege, T. (2019) Mainstreaming Disaster Risk Reduction into Housing Development in Keko Machungwa. Journal of Environmental Protection, 10, 315-336.

https://doi.org/10.4236/jep.2019.102018

Received: January 17, 2019

Accepted: February 16, 2019

Published: February 19, 2019

Copyright $\odot 2019$ by author(s) and Scientific Research Publishing Inc. This work is licensed under the Creative Commons Attribution International License (CC BY 4.0).

http://creativecommons.org/licenses/by/4.0/ (c) (i) Open Access

\begin{abstract}
In Tanzania $80 \%$ of the population live in informal settlements. Most of these settlements are built in areas that are susceptible to extreme weather conditions such as flooding. Such conditions have significantly contributed to the destruction of housing stock and other valuable properties. There is considerable awareness amongst people living in the informal settlements, government representatives and other key stakeholders about the various flood risks affecting informal settlements. Based on this understanding, several attempts to minimize flood risks have been initiated in Dar es Salaam, Tanzania, yet these initiatives have largely failed to deliver the desired impacts. This article aims to investigate core reasons for this through a case study of Keko Machungwa Informal settlement in Dar es Salaam City. The study explores the extent to which mainstreaming of disaster risk reduction (DRR) in housing development in informal settlements has been considered and implemented, and recommends measures for improvement. Key methods employed for the research included physical observation, household interviews, mapping, photographing, and in-depth interviews. Overall, the study found that mainstreaming of DRR in housing development was hardly practiced at the household level, as houses were predominantly being built without resistant building materials and supervision of relevant professionals. In order to mainstream DRR in housing development in informal settlements, it is recommended that mainstreaming DRR be embedded in laws and policies, highly vulnerable parts of the settlement be declared protected wetland and that the government direct its efforts towards regulating, controlling and monitoring the housing development sector. That letter can be achieved by emphasizing the use of flood resistant building materials and establishing resilient infrastructures for flood mitigation in every flood prone informal settlement.
\end{abstract}

\section{Keywords}

Disaster, Disaster Risk Reduction, Flooding, Housing, Housing Development, 
Mainstreaming

\section{Introduction}

In Tanzania $80 \%$ of the population live in informal settlements [1]; this means that informal settlements have a significant contribution to solving the housing problem over and above the capacity of the government. A number of Acts and policies in Tanzania recognize the significance of informal settlements in solving the problem of housing in urban areas. These include the Land Policy of 1997, the Human Settlements Development Policy 2000, Land Act 1999 (Act No. 4 of 1999) and Urban Planning Act 2007 [2] [3] [4] as well as MKURABITA Programme [5]. Although there are laws and policies which recognize the importance of informal settlement in solving the housing shortage, it is argued by many scholars that little attention has been paid to addressing disaster risk in these informal settlements [6] [7]. Certainly, many projects in Tanzania initiated for the purpose of spatial reorganization of informal settlements and improving physical infrastructures ${ }^{1}$ have been unsustainable. For example, government has implemented various strategies to ensure that environmental conditions in informal settlements are improved to reduce disaster risk. The strategies included regularization and squatter upgrading programmes. In principle, these strategies aimed at improving the physical infrastructure so as to minimize disaster risk in vulnerable informal settlements. Meager financial resources and insufficient management capabilities have undermined these projects. Squatter upgrading, which was introduced in the 1970s by the World Bank, collapsed in the middle of the 1980s [8].

Nevertheless, Kombe and Kreibich [9] noted that in 1960 there were 5000 housing units in the informal settlements of Dar es Salaam, but they increased to 7000 and 28,000 in 1963 and 1972 respectively. Thirty years later as reported by UN-HABITAT [10], $68 \%$ of the total population in Dar es Salaam city lived in informal settlements. As time goes on, the situation of the growth of the informal settlements and number of people living in these settlements is becoming dire. Lupala et al. [11] also established that $66.34 \%$ of the spatial form in urban Tanzania was occupied by informal settlements. In addition, recent studies by Sakijege et al. [1] and Kyessi and Tumpale [12], in the city of Dar es Salaam, showed that up to $2014,80 \%$ of all residential houses were found in informal settlements. The increase in the number of informal settlement and the increase in the number of people living in informal settlements are a challenge in developing countries. It is a challenge because most of the informal settlements are often located in marginalized, low-lying and environmentally fragile areas that are susceptible to extreme weather conditions including flooding [1] [7] [13]. This

${ }^{1}$ Physical infrastructure includes dwelling structures; basic urban services, such as water, drainage channels and sanitation facilities; social amenities like schools and health facilities. 
condition has significantly contributed to the destruction of housing stock and other valuable properties.

There is considerable awareness amongst people living in the informal settlements, government representatives and other key stakeholders about the various flood risks affecting informal settlements. Based on this understanding, several attempts to minimize flood risks have been initiated in Dar es Salaam, Tanzania yet these initiatives have largely failed to deliver the desired impacts. Indicators which show that the initiatives to minimize flood impact have failed are diverse, and include problems like dampness, destruction of properties, water logging to mention but a few [1]. Given this background it is worth investigating reasons for increased vulnerability of buildings and structures in informal settlements in the search for practical intervention measures.

Findings from previous studies that address disaster risk have focused on aspects including, perceptions and practices within international aid organizations regarding the existing and potential roles of urban planning as a tool for reducing disaster risk [14], assessment of adaptation strategies to flooding [1], Mainstreaming disaster risk reduction into development [15], mainstreaming DRR in urbanization [16]. Yet, in these studies, mainstreaming DRR in housing development in informal settlements is hardly addressed. There are very few analyses on how aspects of disaster risk reduction are applied in housing development in areas that are prone to flood disasters. Many scholars have argued that houses and structures meant to prevent disaster (particularly flooding) are destructed during rainy season and thus aggravate flood hazards [1] [14]. This warrants the rationale for conducting this research, with Keko Machungwa informal settlement in Dar es Salaam City Tanzania being the case study under investigation. The aim of this research was to understand the process of housing development in flood prone areas and identify underlying factors contributing to risk. Based on research findings the final part of the paper outlines important recommendations for mainstreaming DRR into housing development in flood prone informal settlements.

The main objective of the study was to explore the extent to which DRR is considered in housing development in the flood prone informal settlement of Keko Machungwa. Studying how DRR is considered in housing development was central for ensuring that these housing structures were reliable in protecting people and properties against flooding. However, before exploring extent to which DRR is considered in housing development, it was important to explore process of housing development.

\section{Growth, Risks and Vulnerabilities of African Informal Settlements}

Informal settlements are not new; they are a common phenomenon in many developing countries only that they are known by different names. For example, they are known as Kampungs in Indonesia, informal/unplanned settlements in 
Tanzania, Squatter settlements in Kenya, and slums and shantytowns in South Africa [1] [17]. This implies that a number of countries suffer from the growth of informal settlements, representing the worldwide phenomenon.

High rate of urbanization is among the causes of the growth of informal settlements and the corresponding increase in poverty. This is so because among the key challenges resulting from rapid urbanization in developing countries is the proliferation of settlements as a result of increasing urban growth and poverty Africa [18]. Growth of the informal settlements is also largely influenced by the rapid population growth which is taking place in the context of low economic growth and financial deficit. The deficit tends to impede efforts of providing planned plots for housing and basic services Africa [19].

Informal settlements as one of the urbanization challenges were expected to be tackled by urban planning [20]. Kochtitzky et al. [20] further note that, urban planning is supposed to ensure that the community's requirements such as housing, healthcare infrastructure, water supply, natural resource utilization, accessibility and good living condition are available in sufficient levels to meet the rapidly changing urban population. However, the situation is different; many countries around the world, mainly in the Global South, lack implementation of proper urban planning policies [19] [21]. Inadequate urban planning coupled with rapid population increase has led to the growth of informal settlements. So far it is estimated that the majority (between $75 \%$ and $99 \%$ ) of Africans live in informal settlements [22] [23].

Informal settlements like any other built up areas, are supposed to be in good condition and served with functional infrastructure such as roads, water supply, drainage system and electricity. Unfortunately, informal settlements in Tanzania are characterized by inadequate or lack of infrastructure and/or services. Informal settlement are built and developed in hazard prone areas such as marshy, flood plains, valley, areas and watercourses [1] [24].

Despite the fact that informal settlements are located in hazardous areas, they have been the refuge of the vast majority of urban population. About 80 percent of the houses in Tanzania for example are found in informal settlements [1]. High concentration of houses, population density, poor planning, unregulated building regulations coupled with deprived locations of informal settlement as a result of urban growth multifaceted existing vulnerability.

Informal settlements in Kenya and Afghanistan portray example of informal settlements in developing countries. Residents in the informal settlements of Kenya face the problem of inadequate housing, little access to water, sanitation and other basic services, and the ever-present threat of forced eviction [25]. Insecurity and political changes are the prime factors that have contributed to the growth of informal settlements in Kabul [26]. Generally informal settlements in developing countries have not received adequate development attention because of the discrepancy between the formal stance of the government and the reality on the ground. This serious discrepancy situation contributes significantly in 
exposing the settlements to high levels of vulnerability.

\section{Mainstreaming Disaster Risk Reduction}

Disaster risk reduction focuses on reducing vulnerabilities and exposure stemming from development within high risk zones, unplanned urbanization, environmental degradation, population growth and climate change. The most commonly cited definition of DRR is one used by UNISDR "The concept and practice of reducing disaster risks through systematic efforts to analyse and manage the causal factors of disasters, including through reduced exposure to hazards, lessened vulnerability of people and property, wise management of land and the environment, and improved preparedness for adverse events" [27]. This definition means that disaster risk reduction is vital for building a more equitable and sustainable future.

The widespread failure of governments across sub-Saharan Africa to deal with disasters before they happen has led to destruction of properties [28], diversion of resources into disaster response which have economic implications for state provision of social services [29] and loss of human life. To make the world safer from disaster risks many plans have been established. For example, the Hyogo Framework's goal was to substantially reduce disaster losses by 2015-in lives, and in the social, economic, and environmental assets of communities and countries [30]. Since its establishment in 2005, disasters caused total economic losses of more than $\$ 1.3$ trillion, made 23 million homeless, and killed more than 700,000 people [31]. This shows that more efforts are needed to minimize the underlying risk factors. Of recent DRR initiative at global level are guided by the Sendai Framework for DRR 2015-2030 [31].

There is no more important factor in reducing a community's risk from flood disaster than mainstreaming the disaster risk reduction in every development undertaken in a flood prone area. Mainstreaming disaster risk reduction in the housing sector means that:

All housing related interventions have considered the effect of natural hazards (current as well as future risks magnified by climate change) and of the impact of those interventions in turn, on vulnerability to natural hazards, and accordingly have adopted risk reduction measures [32].

This definition implies that incorporating disaster risk reduction measures when developing a house and flood mitigation measures is imperative for sustainable flood management.

Moreover, there is a need for controlling the quality of houses to withstand adverse flood impact. Good quality house can particularly be achieved where building codes exist and followed, since the main purpose of building codes are to protect public safety as they relate to the construction of buildings and any other structures [33]. They specify the minimum requirements to adequately safeguard the health, safety, and welfare of building occupants. Similarly poor maintenance of houses increase vulnerability of a house to various disaster [34], 
because it weaken the structure and thus easily destructed when disaster happen. It should be noted that maintenance is a disaster prevention strategy [29]. Proper maintenance of structures is crucial for minimizing potential adverse impacts of flood and minimise the need for recovery and reconstruction [34].

Additionally, where urban drainage facilities that are meant to contain flooding at the community are insufficient the impacts go directly to individual households [35]. This imply that where the adaptation strategies at the society are limited in their effectiveness to protect the whole community, the degree to which individual household will be affected or not depends on how best they have incorporated disaster risk reduction measures in the process of developing their houses as well as adaptation strategies.

For the purpose of this study, disaster risk reduction measures will combine the following elements Structural integrity (adherence to building code), Building materials, Maintenance of structures, Quality and safety settlement (adaptation strategies at community level), and regulatory mechanism to enforce land use/building regulations.

\section{Previous Study on Disaster Risk Reduction}

There is a wide range of literature on disaster risk reduction [14] [36] [37], a paper by Carcellar et al. [36] identified the ways in which government and other stakeholders can support the needs and address the vulnerabilities of at-risk communities. They noted that flash flood triggered by Typhoon Ketsana in 2009 heavily damaged many houses in poor communities. Through the support programme developed, it was proposed that building materials loans for house repairs should be paid to the affected communities. This conclusion means that, improvement on housing conditions is vitally important in risk reduction.

It was noted by Wamsler [14] that dwellers in 15 slum communities in El Salvador cope with disaster risk, and reveals the variety of strategies they have to reduce risk. The strategies are based on different patterns of social behavior, with a strong focus on individualistic behavior for survival. It was concluded that the applied strategies are huge and crucial but they are weak coping strategies and thus very difficult to protect houses from being affected by disaster and minimize disaster risk in general [14].

Increasing scale of disaster occurrence and impact is a growing concern of all countries and people [37]. Therefore, it is important to understand where and how the disaster occurs in order to deal with it. Likewise it is important to understand knowledge of the affected communities as far as disaster is concerned and how they cope with such a situation, this in turn will make possible implementation/improvement of DRR measures and increase resilience of such community [37].

Disasters impact on all aspects of development [36]; they cause damage to service infrastructure, housing and productive assets, they also cause loss of human. These researchers argued that many developing countries are failing to cope with disasters as a result it create risk through increasing peoples' exposure and 
susceptibility to disasters. They then suggested that DRR strategies are of paramount importance to reduce or manage risk from disasters. Finally, they concluded that it is important to consider how to empower developing countries to initiate DRR strategies. This is because developing and developed countries differ in capacity and because, on average, developing countries are less in capacity than developed countries [36].

These studies highlight that in order to reduce disaster risk there is a need to consider disaster risk reduction measures when building houses in areas that are prone to flood hazard.

\section{Approach to Data Collection and Analysis}

Case study were carried out at the household and institutional ${ }^{2}$ levels in Keko Machungwa in 2015 to document the underlying factors contributing to risk and to determine process of housing development at the household level in Keko Machungwa. Understanding factors contributing to risk and the process of housing development are vital especially when one wants to establish whether or not DRR is being mainstreamed in the process of housing development. Data was collected using multiple qualitative methods and the household level investigation included observation, photographing, semi-structured interviews, and in-depth interviews with selected respondents. Approximately 60 (out of 3129 household in flooding area) of the interviews were conducted with households living in Keko Machungwa informal settlements.

Since the purpose of the research was to explore the extent to which DRR is being mainstreamed in housing development in the informal settlements of Keko Machungwa, purposive sampling was adopted as a viable sampling method for this study. Purposive sampling was employed so as to include household who are affected by floods and exclude those who are not affected by floods. However, to ensure reliability of data sample random sampling was applied when selecting the 60 households to be interviewed. The sample of 60 household was thus selected randomly among the households living in high risk area within the river valley of Keko Machungwa informal settlement. The emphasis was on exploring: the underlying risk factors, the process for housing development as well as DRR initiatives.

Group discussion and semi-structured interview were the main data collection tools used at the institutional level. Institutions interviewed included: sub-ward office (which is the lowest organ of local governance in Tanzania), ward office, engineering department and town planning department of Temeke Municipal Council. The focus of discussion with institutions was on analyzing existing procedures for housing construction and whether those procedures are followed.

It should be noted that, in Dar es Salaam, most informal settlements exist on risky areas which are vulnerable to floods and other hazards [19]. However, flood severity is not equal in all the informal settlements and in order to identify

${ }^{2}$ Institutions include Keko Mwachungwa Sub-ward office, Miburani ward office, engineering department and town planning department of Temeke Municipal Council. 
and select a case suitable for conducting the study, four criteria were developed for evaluating potential sites; these were 1) an area where residents have been affected by frequent floods, 2) the immediate impacts of flooding e.g. damage to houses, among others, 3) good practice cases (the residents are proactive in learning and implementing different ways to curtail floods) and 4) accessibility and possibility for doing research. On the basis of the aforementioned criteria Keko Machungwa informal settlements was chosen as an appropriate case study settlement for the research.

The area affected by flood is within the valley (Keko Machungwa Bondeni). Geographically, Keko Machungwa settlement is situated about 3 kilometres from the Dar es Salaam City centre. Administratively, Keko Machungwa is one of the subwards within Miburani Ward in Temeke Municipality. Keko Machungwa Sub-Ward lies between latitude $6^{\circ} 50^{\prime} 10^{\prime \prime}$ and $6^{\circ} 50^{\prime} 41^{\prime \prime}$ South and between longitude $39^{\circ} 16^{\prime} 35^{\prime \prime}$ and $36^{\circ} 17^{\prime} 1$ " East. Formerly it was a wetland used for agriculture; it was also a water course accumulating storm water from different elevated parts (for example Kurasini and Chang'ombe) towards the Indian Ocean. The fact that Keko Machungwa is located on a low-lying terrain, and not well drained, it is obvious that the settlement is susceptible to floods. In addition, to being affected by floods, Keko Machungwa has a problem of land use changes within the valley. Indeed, according to the Dar es Salaam Master Plan of 1979 [38], the valley was earmarked as a hazard land. At present it is no longer considered as hazard land, instead it has been turned into settlement for shelter informally. It should be noted that Keko Machungwa Informal settlement is located about $3 \mathrm{~km}$ from the city centre and close to industrial areas of Chang'ombe $(2 \mathrm{~km})$, and as such the proximity to important areas attracted residents and investment (despite being a flood prone area). This in turn led to high population density and concentration of buildings. Therefore, the settlement is expanding in term of increasing in the number of people and buildings, which in turn triggered disaster risks.

\section{Flooding and Mainstreaming Disaster Risk Reduction: Findings}

\subsection{Settlement Vulnerability to Flood Disaster}

As stated in Section 5, Keko Machungwa informal settlement lies within the Keko Machungwa River valley (see Figure 1), which frequently experiences flooding caused by heavy rains. The rain is therefore relatively high during heavy rainy season (March-May). Risk of flooding in the settlement is aggravated by encroachment on river valley, absence of robust flood control infrastructures, haphazard dumping of solid waste, and concentration of buildings.

"I did not like to build my house very close to this river (Figure 2); I was forced to do so due to the low cost of plot. I wish to relocate because this place is not healthier to live, during rainy, flood water fills every part of the house and the floor get damaged by water due to underground water percolation". 


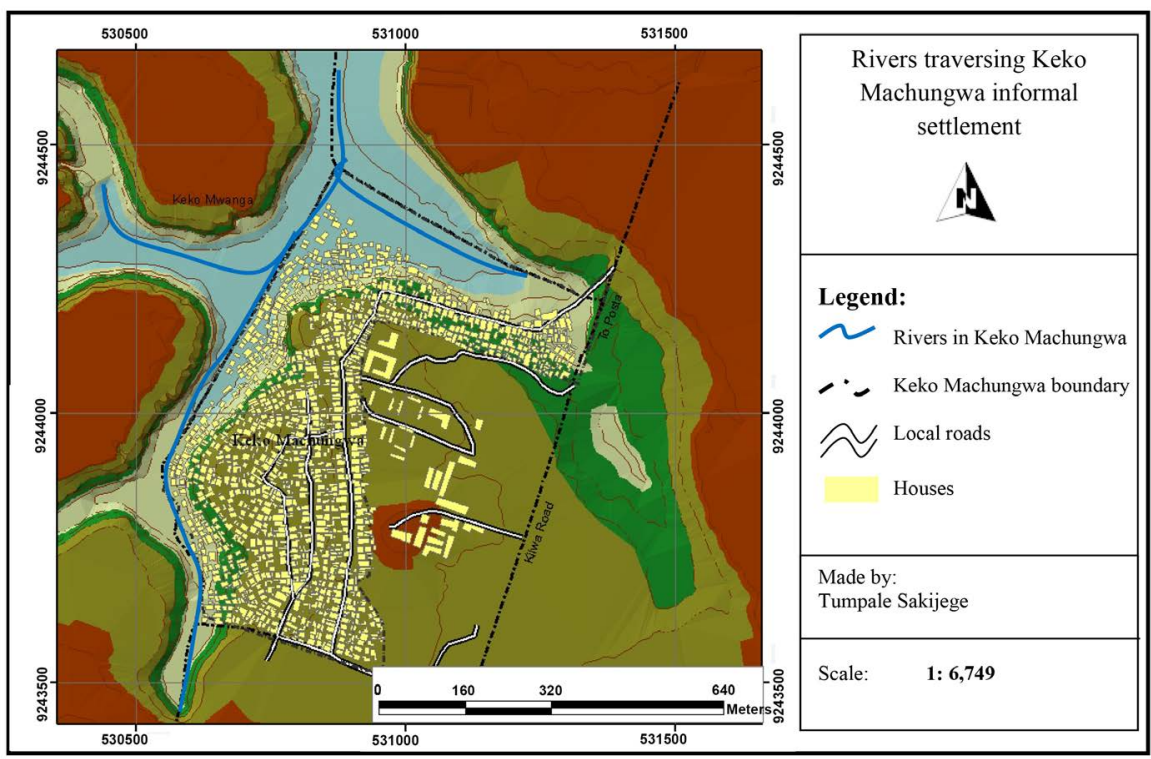

Figure 1. Rivers traversing Keko Machungwa informal settlement.

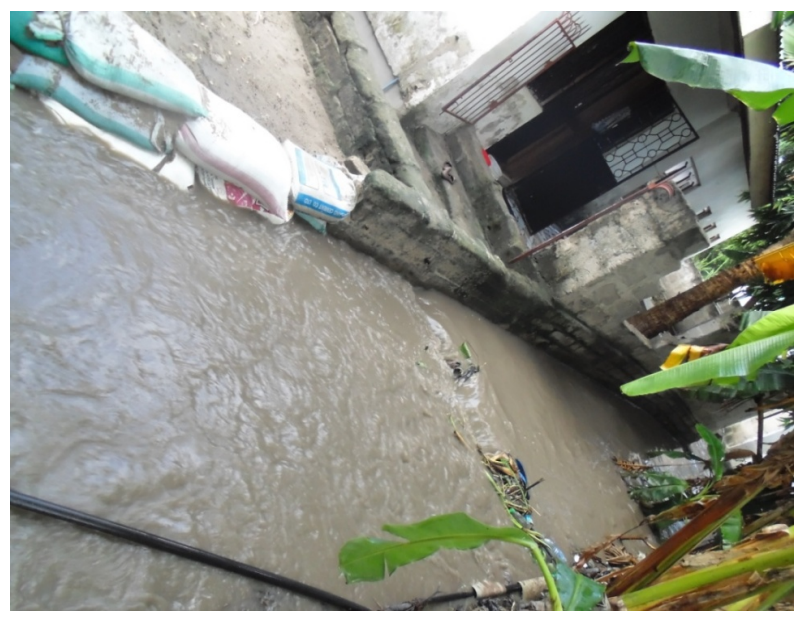

Figure 2. A house constructed at the edge of the river in Keko Machungwa. Source: Photographed by T. Sakijege.

Although the above statement was the opinion of an individual, it shows how vulnerable the settlement is. Furthermore, the damage that happens to the floor is a sign of disregard of DRR strategies (like the use of flood resistant building materials) when constructing their houses.

The factors that increase the risk of flooding in Keko Machungwa are summarised in Figure 3. The most severe floods recorded in Keko Machungwa and Dar es Salaam City, in general, was the flood event of December 2011, causing estimated deaths of 40 people and over 1000 families displaced [5]. The Keko Machungwa informal settlement was one of the sub-wards affected by floods in 2011; in addition, the settlement has been affected by floods every year during rain season, although intensity of floods depends on the amount of rainfall for that particular year. 


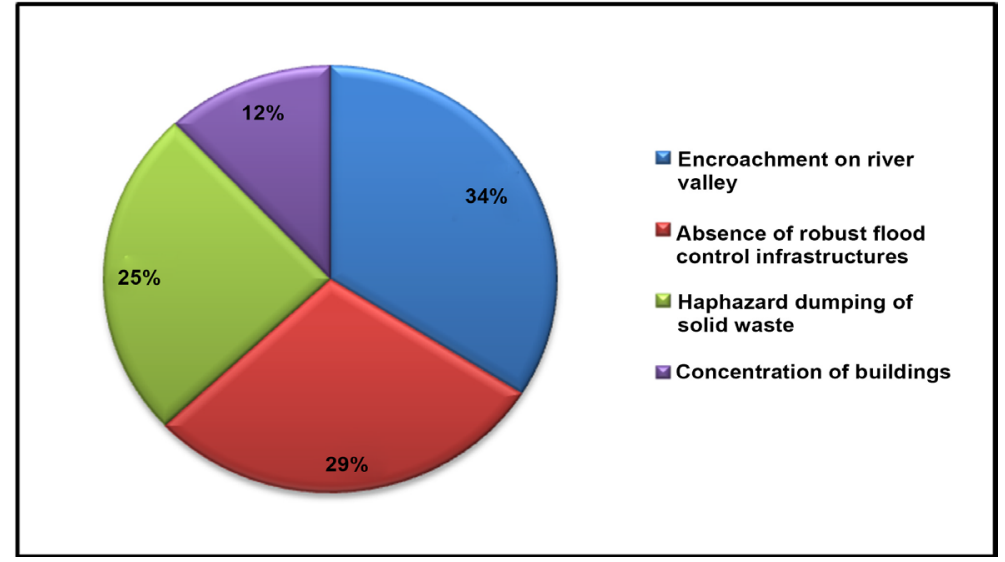

Figure 3. Factors that increase the risk of flooding in Keko Machungwa informal settlement.

"As you can see my house is flooded (Figure 4). In fact, we are frequently affected by floods in every rainy season; it is very hard to specify how many times we experience floods. Sometimes we are affected by floods even though it is not raining here, this is due to rainfall from surrounding upper areas. Rainfall intensity determines frequency of flood; a good example is the heavy rainfall in 2011 where flood depth was 1.5 meters".

The statement above is a quote captured during household interview when one woman explained about the frequency of floods in the area. In practice, the respondent's statement means that Keko Machungwa is affected by floods in every rainy season, and the frequency of floods depends on rainfall intensity. The area is also affected by floods as a result of rainfall from upper catchment areas.

\subsection{Adaptation Strategies Undertaken to Reduce Flood Risk}

As a way of reducing impacts of flooding, residents in Keko Machungwa informal settlements have resorted to the use of structural adaptation strategies. Some of them include Protective wall; raised foundation; raised pit-latrine; raised plinth, in Disaster. These strategies are referred to as structural adaptation strategies. The uses of these strategies were meant to block flooding water. Figure 5 illustrates survey results of the adaptation strategies to flooding in Keko Machungwa settlement.

According to Figure 5, construction of protective walls is one of the options preferred by residents in Keko Machungwa, it was revealed by $37 \%$ of the respondents. A protective wall is a defensive structure which is built as a fence surrounding a house. One household reported that:

"I constructed this wall for protecting flood water from entering my house; however the wall is useless because even if there is little rain my compound gets filled with rain water, we are therefore forced to stay with this wet condition for a month. In the period of heavy rainfall the wall is helpless. Water overflows them and enters inside the house". 


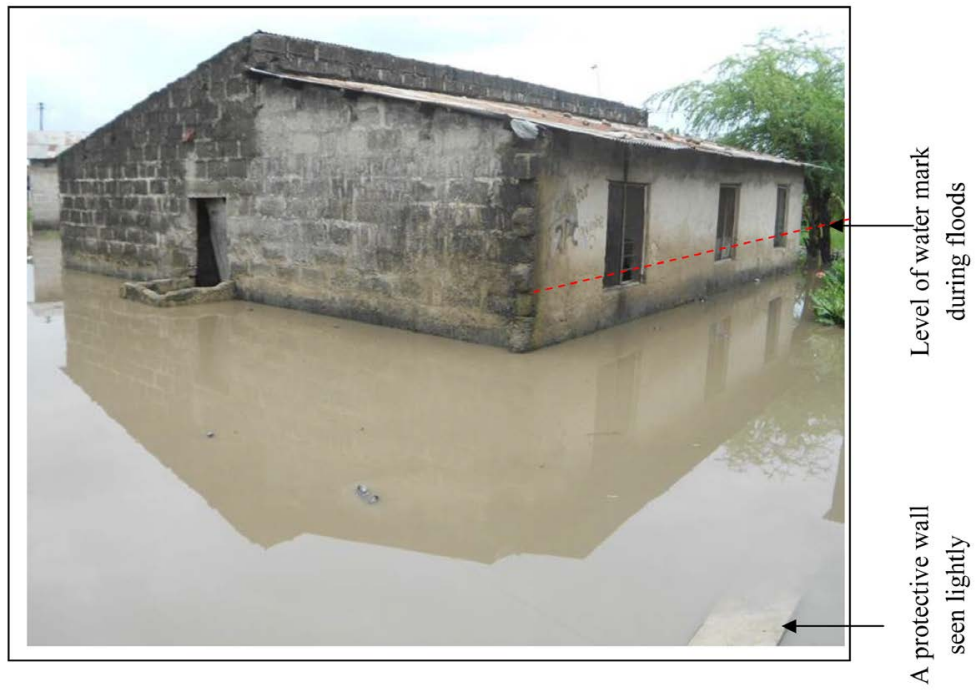

Figure 4. One of the respondent's houses surrounded by floodwater. Source: Photographed by T. Sakijege.

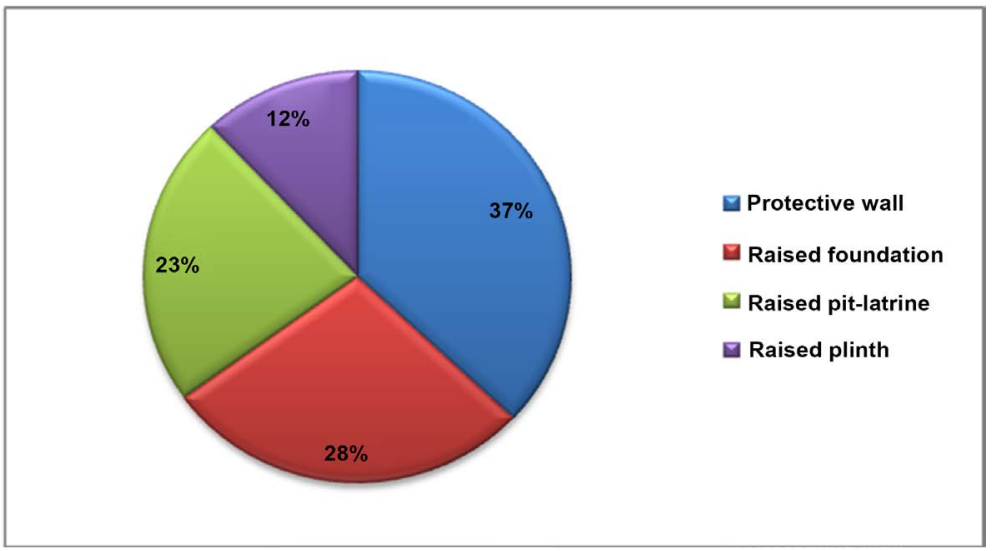

Figure 5. Adaptation strategies in Keko Machungwa.

The above explanation shows one of the adaptation strategies (protective wall) that were applied by a respondent to reduce the impact of flooding and the way they are not helped with the effort they had taken. This means that, given the high water table, it is possible during heavy rainfall to have flood that cannot be contained by the available strategies.

As a result of flooding and the fluctuating water table, some households raised their foundations of their houses and pit latrines to prevent the storm water from filling up their houses and pit latrines. Of 60 interviewed households, 28\% had raised foundation of their houses and $23 \%$ had raised their pit latrines. The height of the raised foundation and pit-latrines depends on the financial ability of individual household, but the height range from 0.5 to 1 metre above the plinth level. It was reported by one interviewee that:

"What I want is someone to assist me move out of this place. I am tired of spending large part of the little income I get to reconstruct my toilet which has been collapsing regularly". 
Drawing from the above quote one issue is pertinent: DRR is hardly practiced when constructing the houses as well as adaptation strategies. Generally, it was determined that flood mitigation and risk minimization measures through the above mentioned intervention were hardly achieved at the household level, as adaptation strategies were constructed with no attention to DRR measures.

\subsection{Housing Development Processes}

Building of houses together with infrastructures to prevent flooding in Keko Machungwa informal settlement does not differ with other informal settlements in Dar es Salaam city. A common building practice that is being used is through untrained local artisans. Out of 60 interviewed households, 57 (equivalent to 95\%) admitted to build their houses and infrastructures to cope with floods through untrained local artisan. One of the questions raised during interview was how do you get a plot and what type of method do you use to build a house? $83 \%$ reported to buy their plots informally, after purchasing they seek for untrained local artisans who builds such houses 1) at a cheap price, 2) without any house layout plan and 3) without any breakdown of the types of building materials relevant to the local conditions. Houses and even flood prevention infrastructures are built on the experience of the untrained local artisans as well as by copying from other people who live in this area or somewhere else. Similarly it was reported that buildings in Keko Machungwa are built without application of building permits from the responsible authorities, also there is no building inspection conducted by the responsible authorities. Figure 6 provides a summary of land development stages/process in Keko Machungwa.

Figure 6 shows that constructions of houses as well as other structures within the settlement (for example structural adaptation strategies) are contingent upon local artisan (refer Stage 5). It should be noted that, local artisan are untrained, they therefore do construction activities based on experiences. In support of this argument one household reported that:

"I like using local artisan because they are easily available within our settlement and they charge relatively low price compared to engineers".

Where structures are designed and constructed by untrained local artisan, it is very hard to have structures that can withstand adverse flood action. With the practice of using untrained local artisan in the design and construction works, the inevitable conclusion is that the vulnerability of buildings is increased.

Moreover, because Keko Machungwa is a flood-prone area, it was expected that, care must have been taken in the selection and purchase of building materials and hence construct houses that are resilience to flooding. The act of developing land with the use of untrained local artisan means that consultation and supervision by engineers is ignored; therefore, it is very difficult to have buildings that can withstand flooding for a prolonged period.

\subsection{Structural Integrity (Building Code Followed?)}

Although Tanzania has many laws prohibiting construction of houses in high-risk areas (for example Environmental Management Act, Act No. 20 of 2004 


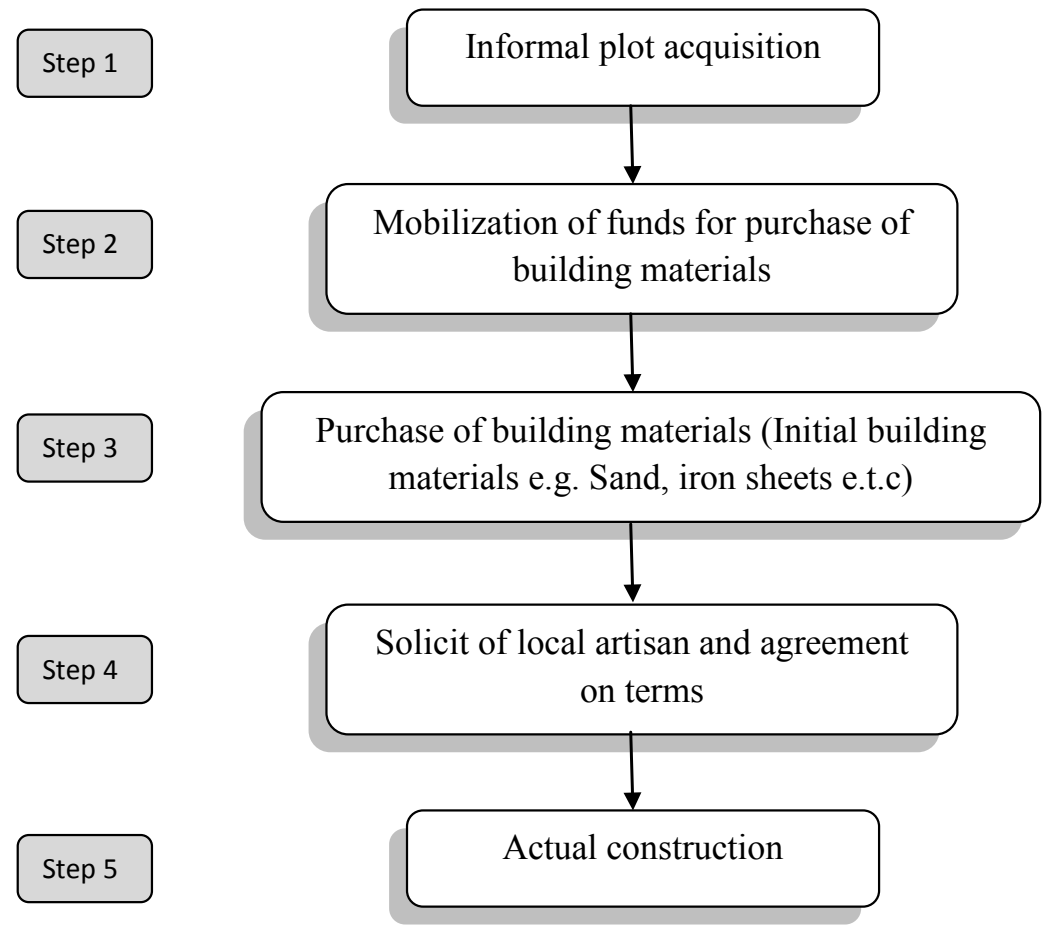

Figure 6. Land Development Process in Keko Machungwa. Source: Household Interview, June 2015.

[39], there is inefficiency in the implementation of these laws. As such many have consequently built their houses in high-risk areas. $71 \%$ of the interviewed households reported that they prefer building in such areas due to 1) low cost of plot, 2) bureaucratic procedures of accessing plots in planned areas as well as 3) absence of specific building codes for housing development in informal settlements. Through interviews with officials it was established that a number of houses are being constructed without building codes that govern the design, construction, alteration, and maintenance of such houses. $81 \%$ of the interviewed households conceded that their houses were constructed without following building codes. Since the purpose of building codes is to have houses that can withstand floods, non-compliance with these codes results into construction of unsafe buildings hence increase vulnerability of various disasters.

\subsection{Building Materials}

It was observed that there were variations in terms of building materials used to construct houses which impacted durability of the houses. $86 \%$ of the interviewed households in Keko Machungwa reported that building materials used for construction of houses (from foundations to walls) consisted of sand and cement blocks. On the other hand, the remaining $14 \%$ of interviewees reported that they construct their houses using soil bricks. These types of building materials are vulnerable to floods when there is a prolonged flood event [40]. The most surprising practice is the way the cement blocks are being produced 1) they are produced by untrained local artisans who do not have modern facilities for 
brick making (Figure 7), and 2) 45 - 50 blocks are being produced per $50 \mathrm{~kg}$ bag of cement, while recommended standard of number of blocks per $50 \mathrm{~kg}$ bag cement is 33 blocks [41]. $72 \%$ of the total households surveyed have been using this old way of block making and the remaining $28 \%$ reported to buy machineries blocks. Due to the fact that majority (72\%) used blocks that are locally produced (using untrained local artisans) it is very common in Keko Machungwa to find many houses being faced with the problem of dampness resulting from underground water percolation.

\subsection{Maintenance of Structures}

"I can not do maintenance in time because of life hardships, sometimes I have to just do maintenance after 5 years, I usually do that after feeling that more damage will occur to my house" (a quote from one of the interviewed household).

"We have the mechanism of going around our settlement after occurrence of every flooding; the aim is to encourage people to do maintenance to the destructed parts of their buildings. However, the response is very poor, maintenance is given low priority for reasons like 1) high cost of living and 2) maintenance is not part of their daily plans of life" (a quote from Keko Machungwa sub-ward leader).

The above quotes as reported by one of the interviewed household and a chairman of Keko Machungwa sub-ward shows that maintenance is not given priority by the residents living in Keko Machungwa. This is despite the fact that

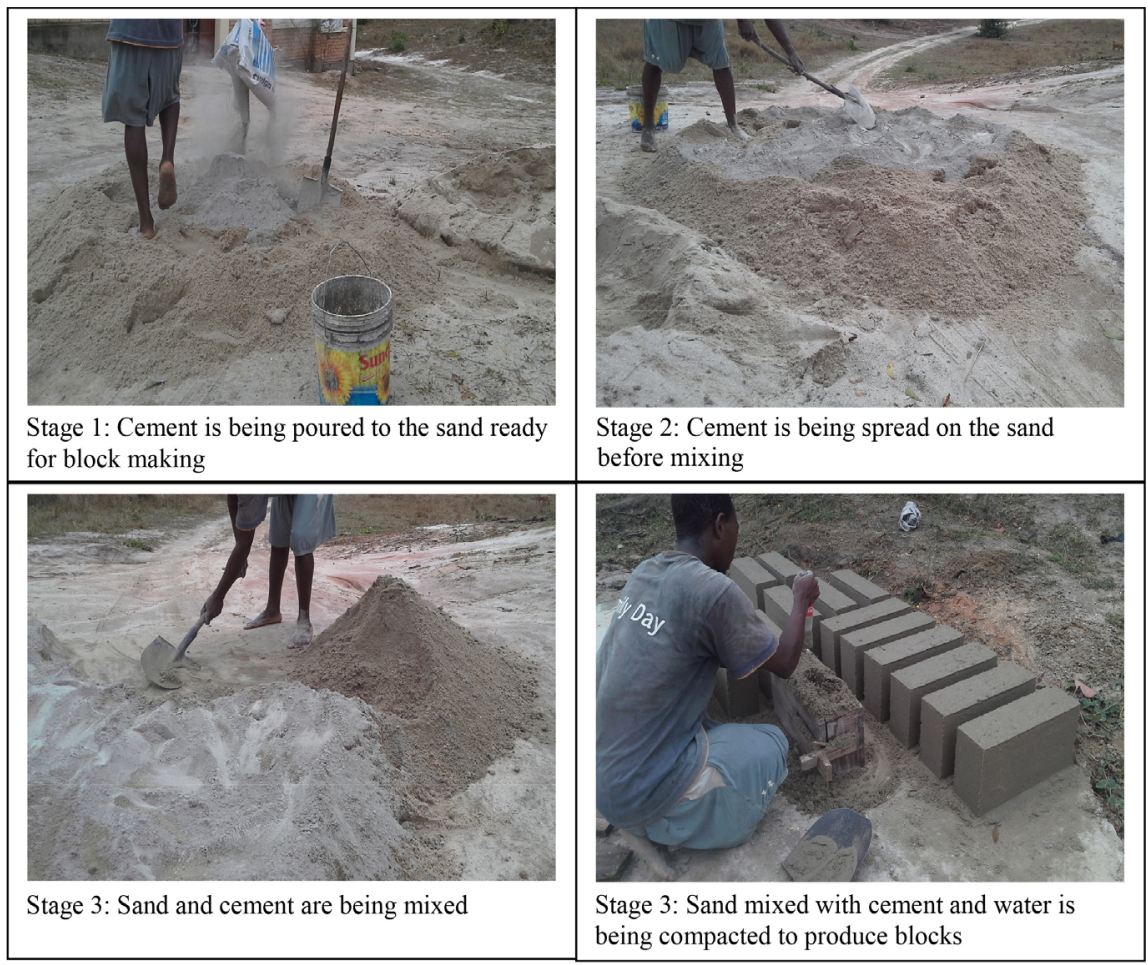

Figure 7. Local way of sand cement blocks manufacturing. Source: Photographed by T. Sakijege. 
the settlement is frequently affected by floods. Likewise, where necessary maintenance is done in a reactive manner, where the size of the damage to the house choose the direction.

Overall, when maintenance of the buildings after flooding was examined, it was revealed the lack of maintenance as reported by $81 \%$ of the interviewed households. One of the reasons reported is that they failed to do their due maintenance of buildings due to construction costs as well as other costs of living. This situation of disregarding timely maintenance of buildings led to weakening of buildings, rendering them vulnerable to failure when severe floods hit the settlement.

\subsection{Quality and Safety Settlement}

Despite the fact that the ability of a house to withstand impacts of floods depends on the adherence to specific construction procedures and the use of flood resistant building materials, availability, suitability and durability of infrastructure to prevent flooding in that specific area has a great contribution in mitigating the effects of floods to the houses. As mentioned in Section 5.1 that, Keko Machungwa settlements is one of the informal settlements that is frequently affected by floods, despite that fact, there are no sincere efforts made to set specific infrastructure (e.g. storm water drains) to prevent/minimize the impact of flooding in the area. Construction of infrastructure to cope with flooding is done by local people themselves without considering quality and flood resistant building materials (see Figure 8). This situation contributed to the increase in settlement vulnerability. Lack of infrastructure to minimize the impact of flooding at the settlement level implies that, the effects of floods go directly to individual households.

\subsection{Factors That Inhibit Mainstreaming Efforts in Tanzania}

Mainstreaming DRR in housing development means that all housing related interventions and disaster mitigation structures consider the effect of natural hazards that are happening and expected to happen in future. In addition it should be noted that, once vulnerability to natural hazards on housing have been considered then disaster risk reduction measures must be adopted.

In order for mainstreaming DRR in housing development to be followed by those who live in flood prone areas, mainstreaming DRR must be incorporated in laws and policies of the particular country. This will be very helpful especially in dealing with legal enforcement and to deal with those who violate the law (not include disaster risk reduction measures in the development of houses and other structures in flood prone areas). In Tanzania for example there is no law and/or policy that put emphasis on mainstreaming DRR in housing development in flood prone areas. This is a very serious constraint especially in an endeavor to reduce disaster risks impacts.

The situation is even worse in flood-prone areas of the informal settlements. Tanzania urban authorities have side-lined planning in informal settlements 


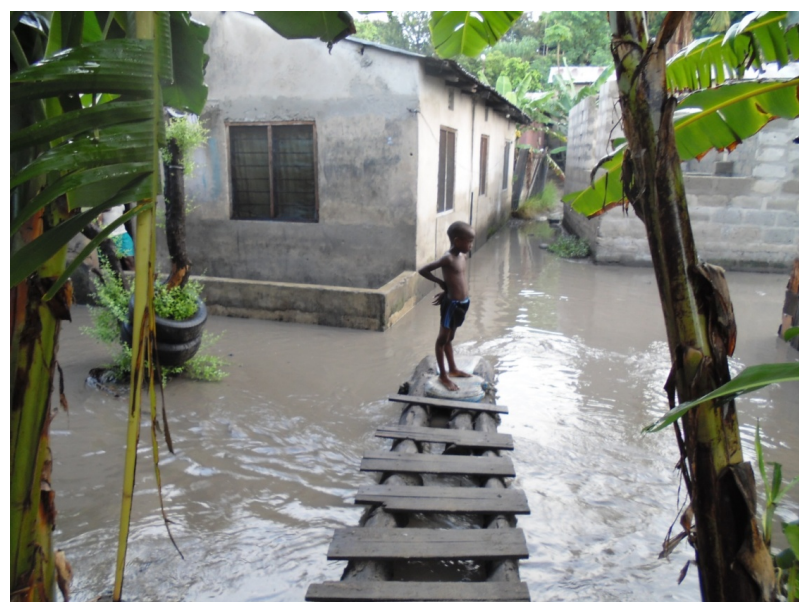

Figure 8. A tree log bridge made by Keko Machungwa residents to simplify crossing in one of the stream traversing the settlement. Source: Photographed by T. Sakijege.

based on the perception that they are problematic and lie outside the planning area. This is the reason as to why construction of buildings in informal settlements does not need to follow the procedures as in planned areas and as listed in Urban Planning Act No. 8 of 2007 [42]. This practice also slowdown mainstreaming DRR efforts to minimize flood risks impacts.

The action of residents living in informal settlement to invest in flood mitigation measures it mean that they realize that floods are dangerous to their homes and their lives in general. The biggest problem that people in these areas face is low level of income, which leads to non-compliance with professional procedures in the construction of houses and flood mitigation infrastructure and thus the structures built are not resilient to flood impact. Therefore, financial constraint is one of the contributing factors that limit mainstreaming DRR efforts in an endeavor to reduce flood risk impacts.

\section{Discussion}

Information provided by the interviewed households indicated that flood is one of the biggest threats to the durability of their houses especially when considering the fact that floods occur frequently. This indicates that residents in Keko Machungwa have a greater understanding on the severity of flooding in their settlement. Under normal circumstances it was expected that this understanding would instigate residents to build strong buildings in order to mitigate the impact of flooding to their houses. Disappointingly, the situation is different from what was expected; whereas, many buildings are built without taking into account the realities of the impact of flooding in the settlement. A major reason for this practice is life hardships (high costs). Cost is likely to inhibit employment of appropriate adaptation measures, as Bubeck et al. assert [43].

While a flood by nature does not constitute disaster risk, underlying vulnerabilities lead to disaster risk and resulting losses. As discussed in Section 5, the 
major factors contributing to the increase in flooding and hence increased vulnerability of buildings and people are encroachment on river valley, absence of robust flood control infrastructures, haphazard dumping of solid waste, and concentration of buildings. Moreover, housing related development in Keko Machungwa does not consider the effects of flooding and mainstreaming of DRR in housing development is not practiced in Keko Machungwa. A number of views were evident with regard to disregard of mainstreaming disaster risk reduction in housing development. Firstly, it was revealed that there is no specific authority to supervise the construction of buildings in Keko Machungwa and in other informal settlements in Tanzania. Thus, in terms of supervision of constructed buildings residents in informal settlements have been doing that by themselves. Secondly, there is lack of skilled human resources for constructing houses. This was evident in the type of human resources used to construct their houses, whereas, it was reported by the majority (95\%) that they use untrained local artisans. The untrained local artisans lack knowledge on the construction techniques that can reduce vulnerability of building stocks in flood prone areas. The findings that absence of specific authority to supervise the construction of buildings and lack of skilled human resources for constructing houses as factors that contribute vulnerability of building stock correspond with scholarly work by RCC [32].

Thirdly, disregard of the use of flood resistant building materials, instead of using material that can withstand flood impact, they use building materials that are easily affected by flooding. About $86 \%$ of the interviewed household uses sand cement blocks. Sand cement blocks according to FEMA [33] are susceptible to floods when there is a long-lasting flood event. Despite disregard of the flood resistant building materials, another thing contributing to the vulnerability of buildings is the way sand cement blocks are being prepared. They are prepared locally, meaning that with the use of untrained local artisan and without considering appropriate ratio of sand and cement. Fourthly, many residents have been ignoring the necessity of maintaining their houses, while maintenance is a core disaster risk reduction strategy.

Flood victims (residents in Keko Machungwa) have attempted to apply certain flood adaptation strategies. However, the initiatives (adaptation strategies) were ineffective in minimizing flood impacts. This is a challenge because despite these efforts, the vulnerability of people and properties in informal settlements is increasing. However, it is an opportunity that residents in Keko Machungwa informal settlement are proactive in taking measures to contain the situation (flood risk), as a way forward, the initiatives at household level need to be enhanced by making sure that mainstreaming DRR is practiced.

Compared to planned areas, where for anyone to build a house construction procedures $^{3}$ must be followed, the action of the absence and disregard of such ${ }^{3}$ Procedures for housing construction in planned areas include 1) application of building permits to relevant authorities, 2) scrutiny of design drawings, 3) site inspections by qualified and authorised personnel, 4) issuing of construction consent and 5) monitoring the construction process. 
procedures in informal settlements implies that the government is not paying adequate attention to the informal settlements.

As mentioned earlier (see Section 4), large parts of Keko Machungwa are on hazardous land, with buildings constructed on waterways, which endangers the lives of residents and buildings, and is contrary to the rules and regulations. Despite this situation, still, there is lack of sincere efforts made (particularly by the government) to build robust flood control infrastructures to prevent flooding in the settlement. Through self-organization residents have ended up building substandard flood control infrastructures (for example tree logs) but most of the infrastructures constructed to minimize impact of flooding does not prevent flood water from affecting their houses. This finding confirmed the argument of WMO/GWP [35] that flood impact to individual household in settlements that lack robust flood control infrastructures at the community level is higher than in settlements which have flood control infrastructures at the community level.

\section{Conclusions and Policy Implications}

Informal settlements have become a refuge for many people living in developing countries despite the fact that most of these settlements are located in flood-prone areas. In order to reduce the impact of flooding on the people and the buildings in flood-prone informal settlements, transition is urgently required from ignoring the quality of houses being built in flood-prone informal settlements towards monitoring all housing related developments to ensure mainstreaming of disaster risk reduction measures. For this to succeed, it will require joint efforts of local people, government authorities, civil societies and disaster experts.

As this study shows, the reason as to why issues associated with mainstreaming DRR are inadequately administered is a serious shortage of trained human resources, absence of law and/or policy that puts the emphasis on mainstreaming DRR, financial constraints and isolation of informal settlement by the existing planning law system. Hence, effective policies will have to provide 1) guideline that can guide appropriate training program for training disaster experts to strengthen human resource capacity to design and develop houses that are resistant to flooding and hence manage disaster risks at all levels; 2) regulating and controlling the construction of structures in informal settlement. It has been learnt in this study that $100 \%$ of buildings in informal settlements are constructed without close supervision by the responsible authorities; therefore, their resilience to flooding is questionable. It is thus recommended that the construction of structures in informal settlements be regulated and controlled.

Where houses have to be built in flood prone locations, design must incorporate construction materials resistance to locally experienced hazards. As a way forward, there is a need to promote the use of flood damage-resistant material so that buildings should not be easily affected by floods. Flood-resistant materials are capable of withstanding direct and prolonged contact with floodwaters without sustaining significant damage [40]. 
Having trained disaster experts and the use of flood damage-resistant material alone are not enough to ensure that disaster risks are minimized in the settlement. Therefore, there is a need to analyze local environment critically to determine the suitable infrastructure that may be constructed to contain and redirect rain water that would otherwise cause floods in the Keko Machungwa community. The Temeke Municipal Council, Sub-Ward government, interested development partners and the local community constitute the key stakeholders in implementing this in Keko Machungwa.

Above all, development control measures, including adherence to provisions in the Urban Planning Act No. 8 of 2007, and Township building rules should be enforced to control development in hazard lands. Moreover, the construction of houses in Keko Machungwa and in other flood prone informal settlement should be regulated and controlled to follow current procedures for housing development. That is following a procedure that involves 1) application of building permits to relevant authorities, 2) scrutiny of design drawings, 3) site inspections by qualified and authorised personnel, 4) requesting and receiving pre-construction inspection, 5) requesting and receiving construction consent and 6) monitoring the construction process to ensure that the prerequisite DRR aspects are considered and implemented.

Since the case study area is an informal settlement developed on fragile land, the law is very clear on such a type of land. It restricts any kind of development on these environmentally sensitive areas. For example, Section 7(1) (b) of the Land Act identifies wetlands in the category of hazard lands, and Section 52 of the Environmental Management Act of 2004 among other issues identifies swamps as environmentally sensitive areas. The National Human Settlements Development Policy of 2000 under Section 4.3.9 identifies invasion of hazardous and fragile areas as among the critical challenges for urban development. In view of this, there is a need to protect such areas from encroachment and hence reduce settlement vulnerability. This is possible because Section 56 of the Environmental Management Act of 2004 gives mandate to the minister responsible for environment in consultation with the minister responsible for lands to protect wetlands? There is a need for responsible authorities to declare part of Keko Machungwa which is highly affected by flood as a hazardous land.

\section{Acknowledgements}

The author is grateful for the academic and moral support received from the late Dr. Samson Elisha Kasala. The support of William Kasyegeta with data collection is gratefully acknowledged. This research did not receive any specific grant from funding agencies in the public, commercial, or not-for-profit sectors.

\section{Conflicts of Interest}

The author declares no conflicts of interest regarding the publication of this paper. 


\section{References}

[1] Sakijege, T., Sartohadi, J., Marfai, M.A., Kassenga, G.R. and Kasala, S.E. (2014) Assessment of Adaptation Strategies to Flooding: A Comparative Study between Informal Settlements of Keko Machungwa in Dar es Salaam, Tanzania and Sangkrah in Surakarta, Indonesia. Jàmbá: Journal of Disaster Risk Studies, 6, 1-10. https://doi.org/10.4102/jamba.v6i1.131

[2] URT (2000) Environmental Management Act [Report]. Government Printers, Dar es Salaam.

[3] URT (1999) The National Land Act No. 4 [Report]. Government Printers, Dar es Salaam.

[4] URT (1997) The National Land Policy [Report]. Government Printers, Dar es Salaam.

[5] URT (2010) Property and Business Formalization Program Experience in Formalization of Squatter Settlements Engaging Citizens in the Process//UNPSA FORUM. New York

[6] Taş, M., Taş, N., Durak, S. and Atanur, G. (2013) Flood Disaster Vulnerability in Informal Settlements in Bursa, Turkey. Environment and Urbanization, 25, 443-463. https://doi.org/10.1177/0956247813501134

[7] Nsorfon, I.F. (2015). Exploring Social Vulnerability to Natural Disasters in Urban Informal Settlements-Perspectives from Flooding in the Slums of Lagos, Nigeria [Report]. Universität zu Köln, Köln.

[8] Kironde, L. (1995) The Evolution of the Urban Land-Use Structure of Dar es Salaam 1890-1990: A Study in the Effects of Land Policy [Report]. University of Nairobi, Nairobi.

[9] Kombe, W.J. and Kreibich, V. (2000) Informal Land Management in Tanzania. SPRING Centre, Faculty of Spatial Plannning, University of Dortmund, Dortmund.

[10] UN-HABITAT (2010) Informal Settlements and Finance in Dar es Salaam, Tanzania [Report]. The United Nations Human Settlements Programme, Nairobi.

[11] Lupala, J., Namangaya, A. and Mbogoro, P. (2013) The Tanzania State of the Cities Report 2013: A Report Prepared under Tanzania Cties Network [Report]. TACINE, Dar es Salaam.

[12] Kyessi, A. and Tumpale, S. (2013) Formalizing Property Rights in Informal Settlements and Its Implications on Poverty Reduction: The Case of Dar es Salaam, Tanzania. In Presentation at the Annual World Bank Conference of Land and Poverty, The World Bank, Washington DC, 8-11.

[13] De Risi, R., et al. (2013) Flood Risk Assessment for Informal Settlements. Natural Hazards, 69, 1003-1032. https://doi.org/10.1007/s11069-013-0749-0

[14] Wamsler, C. (2007) Bridging the Gaps: Stakeholder-Based Strategies for Risk Reduction and Financing for the Urban Poor. Environment and Urbanization, 19, 115-142. https://doi.org/10.1177/0956247807077029

[15] Benson, C. (2009) Mainstreaming Disaster Risk Reduction into Development: Challenges and Experience in the Philippines. International Federation of Red Cross and Red Crescent Societies/The ProVention Consortium, Geneva.

[16] GB Oxfam and Frontiers Development (2013) Mainstreaming Disaster Risk Reduction in Urbanization in Bangladesh: A Scoping Study.

[17] Abunyewah, M., Gajendran, T. and Maund, K. (2018) Profiling Informal Settlements for Disaster Risks. Procedia Engineering, 212, 238-245. 
https://doi.org/10.1016/j.proeng.2018.01.031

[18] UN Habitat (2006) Analysis Perspective of Pro-Poor Slum Upgrading Frameworks. United Nations Human Settlements Programme, Nairobi.

[19] UN Habitat (2009) Planning for Sustainable Cities: Global Report on Human Settlements. United Nations Human Settlements Programme, London.

[20] Kochtitzky, C.S., Frumkin, H., Rodriguez, R., Dannenberg, A.L., Rayman, J., Rose, K., Kanter, T., et al. (2006) Urban Planning and Public Health at CDC. MMWR Supplements, 55, 34-38.

[21] Kasala, S.E. (2013) Operationalizing Strategic Urban Development Planning: The Case of Dar es Salaam. PhD Thesis, University of Dar es Salaam, Dar es Salaam.

[22] Giddings, S.W. (2007) Housing Challenges and Opportunities in Sub-Saharan Africa. International Housing Coalition, Washington DC.

[23] Carrington, D. (2014) World Population to Hit 11bn in 2100-With 70\% Chance of Continuous Rise. The Guardian, 18.

[24] Satterthwaite, D. (2011) What Role for Low-Income Communities in Urban Areas in Disaster Risk Reduction. Documento informativo elaborado para el Informe de evaluación global sobre la reducción del riesgo de desastres.

[25] Githira, D.N. (2016) Growth and Eviction of Informal Settlements in Nairobi. University of Twenty Faculty of Geo-Information and Earth Observation (ITC), Enschede.

[26] Fazli, M. (2016) Factors behind the Growth of Informal Settlements in Kabul.

[27] UNISDR (2009) Terminology on Disaster Risk Reduction. UN International Strategy for Disaster Reduction, Geneva.

[28] Sakijege, T., Lupala, J. and Sheuya, S. (2012) Flooding, Flood Risks and Coping Strategies in Urban Informal Residential Areas: The Case of Keko Machungwa, Dar es Salaam, Tanzania. Jàmbá: Journal of Disaster Risk Studies, 4, 1-10. https://doi.org/10.4102/jamba.v4i1.46

[29] ISDR \& RAED (2013) An Overview of Environment and Disaster Risk Reduction in the Arab Region: A Community Perspective.

[30] Isdr, U. (2005) Hyogo Framework for Action 2005-2015: Building the Resilience of Nations and Communities to Disasters. Extract from the Final Report of the World Conference on Disaster Reduction (A/CONF. 206/6), Vol. 380, The United Nations International Strategy for Disaster Reduction, Geneva.

[31] UNISDR (2015) Sendai Framework for Disaster Risk Reduction 2015-2030, in United Nations. UN International Strategy for Disaster Reduction.

[32] RCC (2011) Mainstreaming Disaster Risk Reduction in Housing Sector, RCC Guideline.

http://www.ifrc.org/PageFiles/95743/24665_24665rccguidelinehousingprintervers.p df

[33] FEMA (2014) The Importance of Building Codes in Earthquake-Prone Communities Fact Sheet. FEMA Report.

[34] Kates, R.W., Colten, C.E., Laska, S. and Leatherman, S.P. (2006) Reconstruction of New Orleans after Hurricane Katrina: A Research Perspective. Proceedings of the national Academy of Sciences, 103, 14653-14660.

https://doi.org/10.1073/pnas.0605726103

[35] WMO \& GWP (2013) Urban Flood Risk Management. Associated Programme on Flood Management, Technical Document No. 1, Flood Management Tools Series, WMO \& GWP Report. 
[36] Carcellar, N., Co, J.C.R. and Hipolito, Z.O. (2011) Addressing Disaster Risk Reduction through Community-Rooted Interventions in the Philippines: Experience of the Homeless People's Federation of the Philippines. Environment and Urbanization, 23, 365-381. https://doi.org/10.1177/0956247811415581

[37] Basher, R. (2013) Science and Technology for Disaster Risk Reduction: A Review of Application and Coordination Needs. UNISDR Report.

[38] Monaghan, M.M. (1979) Dar es Salaam Master Plan.

[39] URT (2004) Environmental Management Act. Government Printers, URT Report, Dar es Salaam.

[40] FEMA (2008) Flood Damage-Resistant Materials Requirements for Buildings Located in Special Flood Hazard Areas in Accordance with the National Flood Insurance Program, in Technical Bulletin. Federal Emergency Management Agency Report, Washington DC.

[41] Simbacement (2016) Production of Sand Cement Blocks. https://simbacement.co.tz/wp-content/uploads/2017/12/BROCHURES-FOR-BLOC K-MAKING.pdf

[42] URT (2007) Urban Planning Act. Government Printers, URT Report, Dar es Salaam.

[43] Bubeck, P., Botzen, W.J. and Aerts, J.C. (2012) A Review of Risk Perceptions and Other Factors That Influence Flood Mitigation Behavior. Risk Analysis: An Interna tional Journal, 32, 1481-1495. https://doi.org/10.1111/j.1539-6924.2011.01783.x 